thus consumes more raw coal than all the railways and gas and electrical undertakings put together. The layman may or may not be aware of the fact that he pays more than twice as much for coal as the large industrial consumer; he certainly does not lnow that at the same time he pays more than double for an inferior product. Scientific classification, analysis, and quantity form the basis upon which industry buys coal; the domestic user just buys coal, so many hundredweights or tons at a time, with no indication as to its quality other than some usually meaningless fancy name, and without any guarantee as to its ash (and stone!) contents, its calorific value, or its nature. He must also buy his 'pig in a poke,' whether he likes it or not; the middleman, while more than doubling the cost of the private consumer's coal, also sees to it that he is steered clear of all such queer new-fangled notions as calories and so forth.

Coal alone does not form, however, the sum of the private consumer's fuel and power requirements; the gas and electricity undertakings are there to push their goods. How pathetic is the domestic user's attitude of indecision when coal, gas, and electrical interests, each and all for themselves, and with all the highly organised and welltrained powers of persuasion at their command, set about convincing him that theirs is the one and only satisfactory solution of his heating problems? It seems to us that the time has come when the domestic user should be able to turn to some disinterested body for unbiased advice as to when, how, and where to use coal and other solid (or liquid) fuels, gas, and electricity; a body which would also see to it that the fuel he bought was purchased on a basis not only of quantity but also of quality. It is useless to attack the domestic open grate fire and to demand its abolition. It is true that when burning raw coal it is the arch polluter of the atmospheres of our cities: but the blood of fire-worshipping ancestors still flows in the Englishman's veins, and to him central heating is an insidious and stuffy abomination and the gas fire a glaring and inhospitable object; the open fire alone can minister satisfactorily to his physiological and psychological needs in the home. Thus, the only remedy for smoke pollution lies in giving the householder a fuel which will burn as well as coal but without smoke, not only on special but also on existing open grates. Up to the present no such fuel has been available, and, until it is, the politician's parrot cry of 'the wicked waste of raw coal on open fires' is meaningless.

A wider interest than the purely technical attaches to the World Power Conference. The proceedings have afforded ample evidence of the efforts that are being made to combine the spirit of individual enterprise with the spirit of cooperation in the examination of all problems besetting those interested in fuels and their utilisation. This spirit of co-operation is being fostered not only between industries which, like the gas and electrical undertakings, were formerly considered to be antagonistic, but also in industry the world over. It would be difficult to overrate the value of this aspect of the Conference towards the firmer establishment of international goodwill ; for, as Sir Thomas Holland pointed out in his opening address to Section $\mathrm{F}$ of the Conference, the surest basis of a wonld peace lies in a mutual understanding and co-operation of economic interests and resources.

\title{
Foot-and-Mouth Disease.
}

$\mathrm{P}^{\mathrm{n}}$ ROGRESS in the prevention and cure of footand-mouth disease is hampered by the fact that no method has yet been devised for cultivating the virus in vitro; and since it cannot be seen, it can only be propagated and recognised by the inoculation of susceptible animals. Further, the control of the disease is rendered more difficult by the fact that at least three types of the virus are known: immunity produced by an attack due to one type does not render the animal any the less susceptible to attack by one of the other types; and, finally, the immunity produced is only relatively short-lived. In spite of these handicaps, the Third Progress Report of the Foot-and-Mouth Disease Research Committee, $1928,{ }^{1}$ gives a detailed account of much research work directed towards increasing our knowledge of the natural history of the disease, and of methods of destroying the virus and of producing immunity in susceptible animals. Owing to the reconstruction of the Experimental

1 Ministry of Agriculture and Fisheries. Third Progress Report of the Foot-and-Mouth Disease Research Committee. Pp. $141+22$ plates (London: H.M. Stationery Office, 1928.) 5s. net.
Station at Pirbright, the work has been confined to experiments on small laboratory animalsguinea-pigs and rabbits,--other rodents possessing a high degree of natural resistance,-carried out at New Haw, the Lister Institute, and the National Institute for Medical Research.

Some attempts to cultivate the virus in vitro were uniformly unsuccessful, even when the oxygen tension of the medium was reduced to nil by the addition to it of small quantities of cysteine (Y. M. Burbury).

The distribution, localisation, and disappearance of the virus in animals after inoculation have been studied by M. C. Maitland, and I. A. Galloway and S. Nicolau : the latter authors have also made an extensive histological study of the lesions in the tongues of rabbits and guinea-pigs. It appears that the predilection of the virus for the soles of the feet and the mucous membrane of the mouth is associated rather with the fact that these areas are subjected to movement and pressure than due to their freedom from hair. If a strip of hairy skin is transplanted on to the sole of a guinea-pig's foot,

No. 3077, VoL. 122] 
vesicle formation will occur in it, whether the virus is inoculated intradermally into the transplant or intramuscularly elsewhere, although lesions scarcely ever occur in hairy skin elsewhere. If, on the other hand, a foot is immobilised and protected by a pad from pressure, vesicle formation does not occur in it following the intramuscular injection of a large dose of virus.

Multiplication of the virus is associated with this vesicle formation, and occurs in both the primary vesicle at the site of inoculation as well as in the secondary vesicles developing upon the feet and tongue within twenty-four hours : infection can be caused by a drop of vesicle fluid diluted a million times. On the other hand, although the virus can be found in the blood and certain of the internal organs for the first three days after infection, it does not apparently multiply in these situations, and no lesions can be discovered in the latter on microscopic examination. In the case of the feet and tongue, virus can be recovered up to the eighth day after infection. It thus appears that in these small animals a process of natural cure takes place, with disappearance of the virus after a few days: very rarely does an animal act as a carrier of the virus for a longer period.

Histological examination of the tongue shows that the earliest evidence of a lesion is degeneration of a small group of epithelial cells : the degenerated area increases in size, a few polymorphonuclear leucocytes wander in and also degenerate, and these disintegrated cells, together with some fluid, form a vesicle, which increases in size and finally bursts, leaving an ulcer, which heals under a scab. Some polynuclear infiltration occurs also in the corium, but a severe inflammatory reaction only occurs if secondary infection of the ulcer takes place.

The immunity produced by an attack of the disease is only short-lived, about 6-12 months : in addition, three distinct types of virus are now known to exist, and an infection by one type will not produce the slightest immunity to either of the others. The blood of an animal recovered from the disease contains antibodies, which can be demonstrated by its power of destroying the virus in vitro.

Adequately to control outbreaks of the disease, knowledge of the power of survival of the virus outside the body and of methods of destroying it is essential. It is known to survive in vesicle fluid, in the epithelium from blisters, and in the internal organs, for months, if chilled, provided the animal was killed during the first few days of infection, since later, as mentioned above, the virus rapidly disappears from the tissues. On a glass slide it will survive for at least two years in chemically dry air; in ordinary moist room air it dies within a week : survival under ordinary conditions is longer on hay and bran than on cotton-wool and filter paper, but in all cases a damp atmosphere has a deleterious influence; thus on moist hay or bran it only lives five days, on dry hay it may survive for several months. In these circumstances methods of sterilising materials likely to be contaminated with virus are of great importance. In vesicle fluid, formalin, phenol, and mercuric chloride have a relatively low disinfectant power as compared with free chlorine or iodine, or potassium permanganate. In the presence of particulate organic matter, however, the value of the oxidising disinfectants is considerably reduced, whilst that of phenol, cresol, or formalin is comparatively unchanged. It was found that spraying hay with one per cent formalin and allowing the solution to evaporate, destroyed the virus dried on it (F. C. Minett). Hides could also be disinfected by soaking for forty-eight hours in the same solution, but unfortunately this treatment affected them deleteriously.

The virus is fairly easily destroyed by heat, a very short exposure to water at $60^{\circ} \mathrm{C}$. being effective : at $50^{\circ} \mathrm{C}$., blood is rendered non-infective after about four and a half hours at this temperature.

The control of the disease, apart from the slaughtering of infected animals, must be based on disinfection of infected material, treatment of infected animals both by specific and non-specific remedies, and finally by prevention of infection by artificial immunisation: it is obvious that if all animals could be rendered immune, the disease would vanish. The fact that immunity is shortlived will always militate against the success of immunisation: on the other hand, there is no evidence at present that wild rodents can carry the disease and act as a source of infection for cattle : rabbits, for example, can be inoculated with the virus and develop the disease, but will not pass it on to others of the same species kept in close contact with them. The problem, then, is that of immunising the larger animals in which the disease naturally occurs.

The method of immunisation by injection of virus of low virulence cannot be of wide application owing to the danger of spread of the infection: injection of serum from an immune animal will only protect for 10-14 days : injection of virus and serum together may produce satisfactory results, but they are too variable for the method to be of much practical use. Vaccination by means of killed virus is the method of choice, provided that a satisfactory vaccine can be obtained. H. B. Maitland has found that a vaccine prepared by exposing the virus to $0 \cdot 1$ per cent formalin at $26^{\circ} \mathrm{C}$. for 48 hours at $p \mathbf{H} \cdot 7 \cdot 6$ gives satisfactory results in guinea-pigs : the immunity is fully established in four days, and is effective for four months, but is not so complete as that produced by injection of living virus, since local inoculation of the feet will produce vesicles, although further generalisation of the disease does not occur. The results, however, suggest that a suitable method of vaccination will soon be discovered. It is also probable that progress in the application of specific prophylactic and therapeutic methods will be aided by the recent observation of Prof. A. Ciuca that the method of complement fixation can be used to show the presence or absence of immunity in susceptible animals.

$$
\text { No. 307, VoL. 122] }
$$

